\title{
Screening of antifungal susceptibility in cave-dwelling aspergilli and report of an amphotericin B-resistant Aspergillus flavus
}

\author{
Erika L.S. Taylor ${ }^{1}$, Gabriella F. Ferreira ${ }^{1,2}$, Gustavo J.C. de Freitas ${ }^{1}$, Rodrigo L. Ferreira ${ }^{3}$, \\ Daniel de Assis Santos ${ }^{1}$, and Maria A. de Resende-Stoianoff ${ }^{1^{*}}$ \\ ${ }^{1}$ Departamento de Microbiologia, Instituto de Ciências Biológicas, Universidade Federal de Minas Gerais, Av. Antônio Carlos 6627, \\ 31270-901, Belo Horizonte, MG, Brazil \\ ${ }^{2}$ Departamento Farmacêutico, Universidade Federal de Juiz de Fora, Campus Governador Valadares, Av. Israel Pinheiro 2000, \\ 35020-220, Governador Valadares, MG, Brazil \\ ${ }^{3}$ Departamento de Biologia, Universidade Federal de Lavras, Campus Universitário, 37.200-000 Lavras, MG, Brazil
}

\begin{abstract}
Caves are stable environments that favour the development of several microorganisms. The aspergilli represent a large number of species isolated from caves including strains capable of causing serious invasive opportunistic infections in humans. Considering that caves may harbour resistant strains to many antibiotics, investigation on the response of opportunistic aspergilli, isolated from pristine and tourist caves to antifungal agents and the mechanisms involved in resistance might be clinically relevant. A total of 32 strains of the species Aspergillus candidus, A. flavus, A. fumigatus, A. niger, A. tamarii, and A. terreus were isolated from caves in the iron quadrangle in Brazil. The strains were tested for their susceptibility to amphotericin $B(A M B)$, itraconazole, voriconazole and terbinafine. One strain was analysed for the mechanism involved in the AMB-resistance, i.e., ergosterol content, lipid peroxidation and enzymatic activity of the antioxidant system. Terbinafine minimum inhibitory concentrations (MICs) ranged between 0.003 and $1.0 \mu \mathrm{g} / \mathrm{mL}$; voriconazole MICs ranged between 2.0 and $>16.0 \mu \mathrm{g} / \mathrm{mL}$; itraconazole MICs ranged between 0.25 and 8.0 $\mu \mathrm{g} / \mathrm{mL}$ and amphotericin B MICs ranged between 0.03 and $4.0 \mu \mathrm{g} / \mathrm{mL}$. The AMB-resistant strain of $A$. flavus was detected with MIC value of $4 \mu \mathrm{g} / \mathrm{mL}$. Resistance to AMB relied on higher ergosterol levels and increased enzymatic activity of the peroxidase and superoxidedismutase, with lower lipid peroxidation. These results enhance the knowledge of natural antifungal resistance in the subterranean ecosystem, and broaden the knowledge about the subterranean microbiota.
\end{abstract}

Keywords: Iron cave, Aspergillus flavus, antifungal drugs, amphotericin B, primary resistance Received 9 December 2016; Revised 12 June 2017; Accepted 28 June 2017

Citation: Taylor E.L.S., Ferreira G.F., de Freitas G.J.C., Ferreira R.L., Santos D.A. and de ResendeStoianoff M.A., 2017. Screening of antifungal susceptibility in cave-dwelling aspergilli and report of an amphotericin B-resistant Aspergillus flavus. International Journal of Speleology, 46 (3), 369-378. Tampa, FL(USA) ISSN 0392-6672 https://doi.org/10.5038/1827-806X.46.3.2105

\section{INTRODUCTION}

Caves are unique ecosystems with environmental characteristics that may favour the growth of several microorganisms (Poulson \& White, 1969; Culver $\&$ White, 2005). The genus Aspergillus has often been reported in subterranean environments and represents many of the identified fungal species isolated from caves (Vanderwolf et al., 2013), including several species capable of causing serious invasive opportunistic infections in humans (Taylor et al., 2013; Vanderwolf et al., 2013; Taylor et al., 2014). The species Aspergillus fumigatus (Perfect et al., 2001), A. flavus (Walsh et al., 2008), A. terreus (Iwen et al., 1998; Mokaddas et al., 2010), and A. niger (Person et al., 2010) are the main causative agents of invasive pulmonary aspergillosis (IPA) in humans (Walsh et al., 2008; Kousha et al., 2011). Although IPA occurs mainly among immunocompromised individuals, cases of pulmonary infection by aspergilli have been reported in immunocompetent individuals (Person et al., 2010; Kousha et al., 2011). The polyenes and azoles are the agents most commonly used in the treatment of IPA. Resistance to these drugs have been increasingly reported (Ghannoum \& Rice, 1999; Singh, 2001; Kousha et al., 2011) raising the possibility of natural acquired resistance (Loeffler \& Stevens, 2003).

Most caves are considered extreme environments due to their oligotrophic conditions. Normally, cave- 
dwelling organisms adapt to this nutrient limitation in order to survive and colonize the ecosystem (Culver \& White, 2005). Among cave microorganisms, this adaptation may occur at the morphological and/or physiological level. Competition for substrate among sympatric fungal species normally leads to production of metabolites capable of eliminating competition, such as antibiotics, acidifying metabolites, and toxins (Griffin, 1994). Antibiotic resistance among cave isolated bacteria has been described as result of genetic background and selective forces involved in various ecological interactions in the subterranean environment (Bhullar et al., 2012). Fungi may also be undergoing the same process, which may cause natural selection of opportunistic and pathogenic strains resistant to currently used antifungal drugs. The fact that several caves have large mats of actinomycetes competing with fungi for substrates and that the most potent antifungal drug (amphotericin B) used in treatment of IPA was firstly obtained from actinomycetes (Streptomyces nodosus) (Svahn et al., 2015), reinforces this hypothesis. Thus, prospective studies on the effect of antifungal drugs against strains colonizing caves are relevant.

Considering that IPA may represent a silent emerging risk to cave visitors, and that caves may harbour strains resistant to antifungals, we conducted a pioneer investigation on the response of opportunistic Aspergillus spp., isolated from pristine and tourist caves, to the most commonly used antifungal agents (amphotericin B, itraconazole, voriconazole and terbinafine) and the mechanisms involved in the resistance to $\mathrm{AMB}$.

\section{MATERIALS AND METHODS}

\section{Study site}

The strains used in this study were obtained from eight different caves located in the Iron Quadrangle (Quadrilátero Ferrífero, Minas Gerais state, Brazil). This region is economically important due to their proximity with the state capital, urban/rural areas and sites with large mining activities (mainly metal ores). Furthermore, cave visitation has increased in past years. The strains used in this study were isolated from seven iron ore caves: Rola Moça II (Brumadinho, Minas Gerais, Brazil- 2003’38.5” S / 4400’30.4” W), Rola Moça III (Belo Horizonte, Minas Gerais, Brazil2002’38.1” S / 4400’23.2” W), Macumba (Sabará, Minas Gerais, Brazil- 1940’01.1” S / 4340’30.1” W), Romeiros (Sabará, Minas Gerais, Brazil- 1949’00.3” S / 4340’35.9” W), Bloco Abatido (Sabará, Minas Gerais, Brazil- 1949’02" S / 4340’50” W), Cascalhinho (Caeté, Minas Gerais, Brazil- 1948'59.1” S / 4340'28.7” W), Eremita (Sabará, Minas Gerais, Brazil- 1949'19.5” $\mathrm{S} / 43^{\circ} 40^{\prime} 49.5^{\prime \prime} \mathrm{W}$ ) and one dolomitic cave, Nossa Senhora da Conceição da Lapa (Ouro Preto, Minas Gerais, Brazil- 20¹8'18.4” S / 43²8'20.6” W) (Fig. 1).

\section{Aspergillus strains}

Five species of aspergilli were selected due to their association as causative agents of IPA in humans. A total of 33 strains of the species Aspergillus candidus (Taylor et al., 2014), A. flavus (Ghannoum \& Rice,
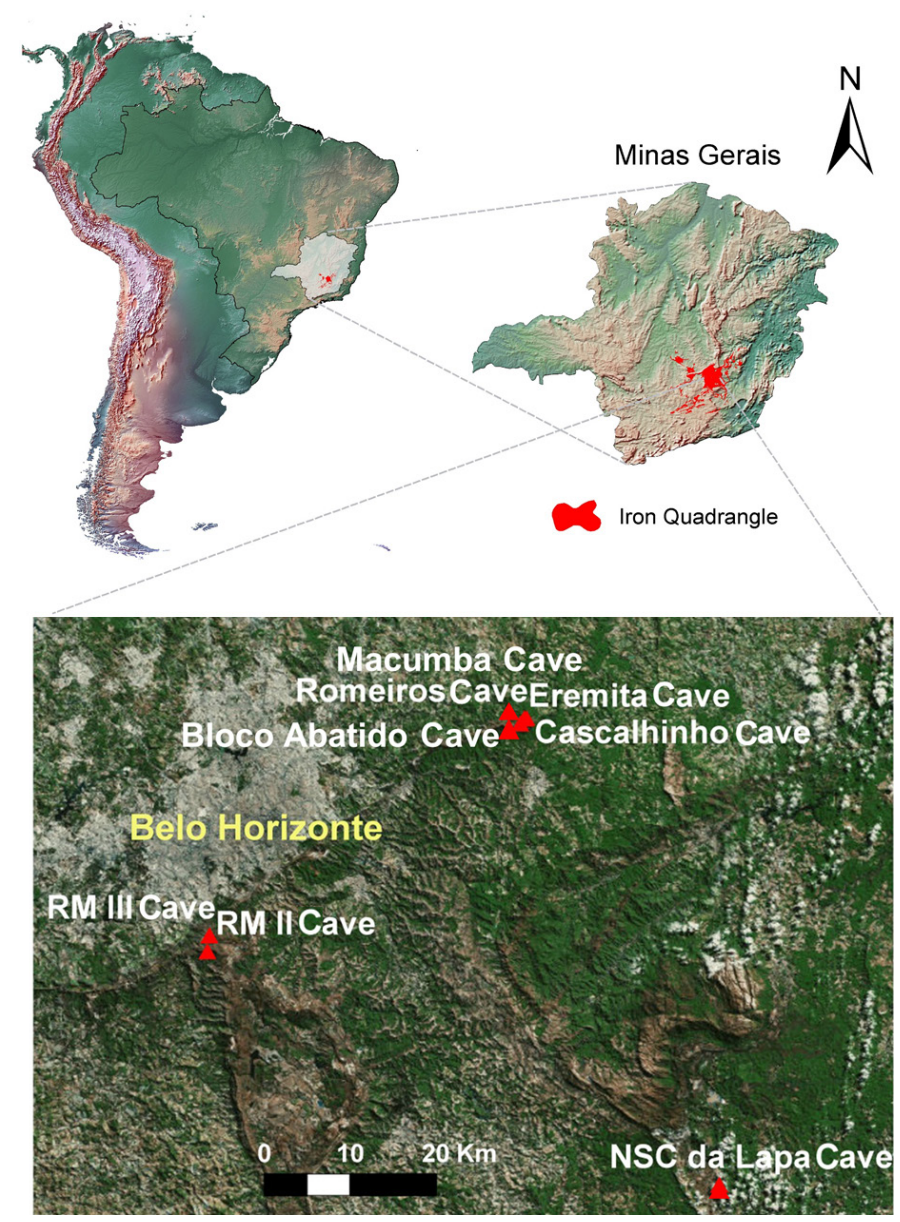

Fig. 1. Location of the eight caves studied in the Iron Quadrangle (Minas Gerais State, Brazil): Rola Moça II Cave, Rola Moça III Cave, Macumba Cave, Romeiros Cave, Cascalhinho Cave, Eremita Cave, Bloco Abatido Cave, and Nossa Senhora da Conceição da Lapa Cave. State capital Belo Horizonte is also indicated.

1999), A. fumigatus (Perfect et al., 2001), A. niger (Perfect et al., 2001), A. terreus (Culver \& White, 2005), and A. tamarii (Culver \& White, 2005) were used that had previously been isolated from the caves during a mycological inventory performed in the period between the years 2010/2013. Strains were sampled from air by the settle plate technique with a 20-minute exposure on Dichloram Rose Bengal Cloramphenicol Agar (DRBC, Acumedia Laboratories, Lansing, MI USA) and Sabouraud Dextrose Agar (SDA, Difco Laboratories, Detroit, MI USA) with cloramphenicol $(0.1 \%)$, and from sediment by a 10-fold serial dilution on DRBC (Acumedia). These strains are currently deposited in the mycological collection of cave fungi in the Mycological Laboratory of the Federal University of Minas Gerais (Laboratório de Micologia da Universidade Federal de Minas Gerais-LM/UFMG, Belo Horizonte, Minas Gerais, Brazil).

Identification of species was confirmed through analysis of macro and micromorphological characteristics in solid media, following standard taxonomic keys and recently published works (Klich, 2002; Domsch et al., 2007). Two media were used for each strain and at different temperature regimens: Czapeck Yeast Extract Agar (CYA, Labsynth, Diadema, SP Brazil) at $25^{\circ} \mathrm{C} / 7 \mathrm{~d}$; CYA (Labsynth) at $37^{\circ} \mathrm{C} / 7 \mathrm{~d}$; and Malt Extract Agar (MEA, Difco) at $25^{\circ} \mathrm{C} / 7 \mathrm{~d}$ (Klich, 2002). 


\section{Thermotolerance assay}

Before initiating the in vitro susceptibility assays, a preliminary triage was performed to exclude strains with negative growth at $37^{\circ} \mathrm{C}$. The media used in this procedure were SDA (Difco) $\left(25^{\circ} \mathrm{C}\right.$ and $37^{\circ} \mathrm{C}$ for 7 days) and Brain Heart Infusion Agar (BHIA, Acumedia) $\left(37^{\circ} \mathrm{C}\right.$ for 7 days). The strains presenting positive growth at $37^{\circ} \mathrm{C}$ were submitted to in vitro drug susceptibility assays to amphotericin B (AMB), itraconazole (ITC), voriconazole (VCZ) and terbinafine (TBF).

\section{Minimum inhibitory concentration (MIC) determination}

The minimum inhibitory concentration (MIC) for AMB (Sigma-Aldrich, St. Louis, Missouri, USA), ITC (Sigma-Aldrich), VCZ (Sigma-Aldrich) and TBF (Sigma-Aldrich) were determined by the antifungal microdilution susceptibility standard test proposed by the CLSI M38-A2 (CLSI, 2008). The inoculum was prepared in sterile saline solution and the transmittance of suspension was adjusted to 68-70\% $(530 \mathrm{~nm})$ as standard protocol for filamentous fungi (M38 from CLSI). This suspension was diluted in RPMI1640 buffered with MOPS (Sigma-Aldrich) medium to achieve $1.0 \times 10^{3}$ to $5.0 \times 10^{3} \mathrm{CFU} / \mathrm{mL}$ (colony forming units per $\mathrm{mL}$ ). The drugs were dissolved in $100 \%$ dimethylsulphoxide according to the protocol of CLSI at $1.0 \mathrm{mg} / \mathrm{mL}$. Final concentrations ranged from 0.03 to $16 \mu \mathrm{g} / \mathrm{mL}$ for AMB, ITC and VCZ and ranged from 0.00195 to $1.0 \mu \mathrm{g} / \mathrm{mL}$ for $\mathrm{TBF}$.

In each case, a volume of $100 \mu \mathrm{L}$ of the inoculum suspension was transferred to sterile flat-bottom 96 well plates containing $100 \mu \mathrm{L}$ of each of the antifungal. Control on RPMI-1640 was also performed (control growth). The plates were incubated at $37^{\circ} \mathrm{C}$ for $72 \mathrm{~h}$. All tests were performed in duplicate (for each strain).

\section{Ergosterol quantification}

Amphotericin B resistant (AmB-R) and amphotericin $B$ susceptible (AmB-S) strains were cultured $\left(37^{\circ} \mathrm{C} / 72 \mathrm{~h}\right)$ on SDA supplemented with $\mathrm{AmB}(1 / 2 \mathrm{MIC}$ concentration) and approximately $10.0 \mathrm{mg}$ of the fungal cell mass were transferred to polypropylene tubes. A growth control was also performed. For the extraction of lipids, $3 \mathrm{~mL}$ of ethanolic solution of potassium hydroxide $25 \%$ were added to each cell mass and agitated for one minute. The tubes were incubated in a water bath at $85^{\circ} \mathrm{C}$ for one hour and cooled at room temperature. A mixture of $1 \mathrm{~mL}$ of sterile water and $3 \mathrm{~mL}$ of $\mathrm{n}$-heptane (Sigma-Aldrich) was added, followed by agitation in a vortex for three minutes. The supernatant was removed and the reading was performed in spectrophotometer at 282 $\mathrm{nm}$ and $230 \mathrm{~nm}$. A calibration curve with standard ergosterol (Sigma-Aldrich) was constructed and used to calculate the amount of ergosterol. The results were expressed as percentage of ergosterol in comparison with the growth control and represent the means of three independent experiments.

\section{Lipid peroxidation assay}

Aspergillus strains were cultured $\left(37^{\circ} \mathrm{C} / 72 \mathrm{~h}\right)$ on SDA supplemented with amphotericin B (1/2 MIC concentration) and hydrogen peroxide (HP) $1 \%$ as positive control. The products of the lipid peroxidation were measured as thiobarbituric acidreactive substances (TBARS). The pellet was frozen and homogenized with $1000 \mu \mathrm{L}$ in ice-cold $1.1 \%$ phosphoric acid using water as diluent (v/v). Four hundred $\mu \mathrm{L}$ of the homogenate was mixed with $400 \mu \mathrm{L}$ of $1 \%$ thiobarbituric acid (Sigma-Aldrich) prepared in $50 \mathrm{mM} \mathrm{NaOH}$ containing $0.1 \mathrm{mM}$ butylated hydroxytoluene and $200 \mu \mathrm{L}$ of $7 \%$ phosphoric acid (all the solutions were kept on ice during manipulation). Subsequently, samples $(\mathrm{pH} 1.5)$ were heated for 60 minutes at $98^{\circ} \mathrm{C}$ and $1500 \mu \mathrm{L}$ of butanol were added. The mixture was mixed vigorously using a vortex and centrifuged for five minutes at $2000 \mathrm{~g}$. The organic layer was transferred and the absorbance was measured at $532 \mathrm{~nm}$ (Termo Scientific Multiscan spectrum, Termo Ficher Scientific). The thiobarbituric acid solution was replaced by $3 \mathrm{mM} \mathrm{HCl}$ in the controls. TBARS values were calculated using the extinction coefficient of $156 \mathrm{mM} / \mathrm{cm}$ and represent the means of three independent experiments. The results were expressed as the ratio between TBARS from cells treated with $\mathrm{AMB}$ or $\mathrm{HP}$ and the values registered in the control $\pm \mathrm{SE}$.

\section{Enzymatic activity of the antioxidant system}

Prior to the tests, a cell-free extract from susceptible and resistant strains of $A$. flavus were cultured $\left(37^{\circ} \mathrm{C} / 72 \mathrm{~h}\right)$ on SDA supplemented with AMB (1/2 MIC concentration) and on positive control with HP 1\% according to the method described by Ferreira et al. (2013). Soluble protein was determined using the Bradford test using a standard curve of bovine serum albumin.

\section{Peroxidase (PER) activity}

The PER activity was analyzed according with method previously used (Ferreira et al., 2013) and measured in a system containing $\mathrm{H}_{2} \mathrm{O}_{2}$ and guaiacol as substrate. Values were obtained by monitoring the absorbance changes at $\lambda=470 \mathrm{~nm}$ using molar extinction coefficient value of $26.61 \mathrm{M}^{-1} \mathrm{~cm}^{-1}$ for the product tetra guaiacol formed by the enzymatic reaction. The data were calculated in nmols/min $\mathrm{mg}^{-1}$ of protein and represent the means of three independent experiments. The results were expressed as the ratio of nmols $/ \mathrm{min} \mathrm{mg}^{-1}$ of protein from cells treated with $\mathrm{AMB}$ or $\mathrm{HP}$ to the nmols $/ \mathrm{min} \mathrm{mg}^{-1}$ of protein from growth control $\pm \mathrm{SE}$.

\section{Superoxide dismutase (SOD) activity}

The SOD activity was measured by the inhibition of pyrogallol autoxidation as described previously (Ferreira et al., 2013). In the test samples, $100 \mu \mathrm{L}$ of cell-free extract was added to pyrogallol and the inhibition of autoxidation was monitored every 30s for three minutes at a wavelength of $420 \mathrm{~nm}$. The unit of SOD was considered as pyrogallol autoxidation per $200 \mu \mathrm{L}$ calculated as follows:

Unit of SOD mL-1 of sample $=(A-B) / A \times 50 \times 100 \times 0.6$ (dilution factor) where $\mathrm{A}$ is the difference in absorbance per minute in the control and $B$ the difference in 
absorbance per minute in the test samples. Data was calculated in units/mg of protein and represent the means of three independent experiments. The results were expressed as the ratio between the units/mg of protein extracted from cells treated with AMB or HP and the units $/ \mathrm{mg}$ of protein from growth control $\pm \mathrm{SE}$.

\section{Statistical analysis}

A Student's two-tailed $t$ test and a one-way analysis of variance (ANOVA) with the Bonferroni multiplecomparison were used to compare the differences among groups. Significance was determined by values of $p<0.05$ in all experiments. The program used was
GraphPad Prism version 5.0 for Windows (GraphPad Software, San Diego, CA, USA).

\section{RESULTS}

A total of 33 strains of Aspergillus spp. were isolated in this study (Table 1). Thirty-two were able to grow at $37^{\circ} \mathrm{C}$. The results of growth and brief characterization of their habitat are shown in Table 1.

\section{In vitro susceptibility data}

The MICs for azoles against the Aspergillus strains ranging between $2 \mu \mathrm{g} / \mathrm{mL}$ and $>16 \mu \mathrm{g} / \mathrm{mL}$ to $\mathrm{VCZ}$, and

Table 1. Aspergillus strains isolated from caves in the Iron Quadrangle in Minas Gerais state, Brazil Growth rate of Aspergillus spp. on Sabouraud Dextrose Agar $\left(25^{\circ} \mathrm{C}\right.$ and $\left.37^{\circ} \mathrm{C}\right)$ and Brain Heart Infusion $\left(37^{\circ} \mathrm{C}\right)$ after seven days of incubation.

\begin{tabular}{|c|c|c|c|c|c|c|}
\hline \multirow[t]{3}{*}{$\begin{array}{c}\text { Taxon } \\
\text { (strain no.) } \\
\end{array}$} & \multicolumn{3}{|c|}{$\begin{array}{c}\text { Growth } \\
\text { (mm) }\end{array}$} & \multicolumn{3}{|c|}{ Habitat } \\
\hline & \multicolumn{2}{|c|}{ SDA } & \multirow{2}{*}{$\begin{array}{l}\text { BHI } \\
37^{\circ} \mathrm{C}\end{array}$} & \multirow[t]{2}{*}{ Substrate } & \multirow[t]{2}{*}{$\begin{array}{c}\text { Zone of } \\
\text { isolation }\end{array}$} & \multirow[t]{2}{*}{ Cave } \\
\hline & $25^{\circ} \mathrm{C}$ & $37^{\circ} \mathrm{C}$ & & & & \\
\hline \multicolumn{7}{|l|}{ Aspergillus candidus } \\
\hline UFMGLMCCO3 & 17 & 8 & 3 & Air & Aphotic & RM 3 \\
\hline UFMGLMCC028 & 20 & 12 & 11 & Sediment & Disphotic & RM 3 \\
\hline UFMGLMCC011 & 20 & 5 & 3 & Sediment & Disphotic & Gruta do Bloco Abatido \\
\hline UFMGLMCC015 & 19 & 18 & 15 & Sediment & Aphotic & Gruta do Cascalhinho \\
\hline UFMGLMCC014 & 22 & - & - & Air & Disphotic & RM3 \\
\hline \multicolumn{7}{|l|}{ Aspergillus flavus } \\
\hline UFMGLMCC04 & 60 & 51 & 50 & Air & Disphotic & Gruta do Eremita \\
\hline UFMGLMCC05 & 62 & 50 & 50 & Sediment & Disphotic & RM3 \\
\hline UFMGLMCC06 & 53 & 47 & 45 & Sediment & Disphotic & Gruta da Macumba \\
\hline UFMGLMCC09 & 62 & 44 & 49 & Air & Photic & Gruta dos Romeiros \\
\hline UFMGLMCC019 & 61 & 60 & 60 & Air & Disphotic & Gruta N. S. Conceição \\
\hline UFMGLMCC021 & 59 & 55 & 52 & Sediment & Aphotic & Gruta N. S. Conceição \\
\hline UFMGLMCC024 & 52 & 49 & 44 & Sediment & Disphotic & Gruta do Cascalhinho \\
\hline UFMGLMCC025 & 63 & 62 & 63 & Sediment & Disphotic & Gruta RM2 \\
\hline UFMGLMCC026 & 70 & 66 & 65 & Sediment & Photic & Gruta Eremita \\
\hline UFMGLMCC027 & 58 & 55 & 59 & Sediment & Disphotic & Gruta RM3 \\
\hline UFMGLMCC030 & 69 & 58 & 59 & Sediment & Aphotic & Gruta N. S. Conceição \\
\hline UFMGLMCC033 & 44 & 49 & 50 & Vegetal debris & Disphotic & Gruta dos Romeiros \\
\hline \multicolumn{7}{|l|}{ Aspergillus fumigatus } \\
\hline UFMGLMCC01 & 61 & 59 & 62 & Air & Aphotic & RM 3 \\
\hline UFMGLMCCO2 & 64 & 60 & 58 & Sediment & Disphotic & Gruta N. S. Conceição \\
\hline UFMGLMCC07 & 57 & 56 & 59 & Sediment & Aphotic & Gruta do Bloco Abatido \\
\hline UFMGLMCC013 & 68 & 62 & 59 & Sediment & Disphotic & Gruta RM3 \\
\hline UFMGLMCC010 & 66 & 69 & 67 & Sediment & Disphotic & Gruta do Cascalhinho \\
\hline UFMGLMCC022 & 64 & 60 & 61 & Sediment & Disphotic & Gruta N. S. Conceição \\
\hline \multicolumn{7}{|l|}{ Aspergillus niger } \\
\hline UFMGLMCC016 & 70 & 68 & 68 & Sediment & Disphotic & RM3 \\
\hline UFMGLMCC017 & 54 & 52 & 53 & Sediment & Disphotic & Gruta RM2 \\
\hline UFMGLMCC018 & 71 & 64 & 61 & Air & Disphotic & Gruta do Eremita \\
\hline UFMGLMCC023 & 69 & 68 & 68 & Air & Disphotic & Gruta do Eremita \\
\hline UFMGLMCC029 & 57 & 49 & 52 & Sediment & Aphotic & Gruta N. S. Conceição \\
\hline UFMGLMCC034 & 62 & 60 & 62 & Sediment & Disphotic & Gruta da Macumba \\
\hline \multicolumn{7}{|l|}{ Aspergillus tamarii } \\
\hline UFMGLMCC012 & 49 & 36 & 39 & Sediment & Aphotic & Gruta N. S. Conceição \\
\hline UFMGLMCC020 & 53 & 53 & 51 & Sediment & Disphotic & Gruta dos Romeiros \\
\hline \multicolumn{7}{|l|}{ Aspergillus terreus } \\
\hline UFMGLMCC031 & 59 & 54 & 50 & Sediment & Disphotic & Gruta do Bloco Abatido \\
\hline UFMGLMCC032 & 62 & 59 & 55 & Sediment & Disphotic & Gruta RM2 \\
\hline
\end{tabular}


between 0.25 and $8 \mu \mathrm{g} / \mathrm{mL}$ to ITC. Itraconazole had lower MIC values, with at least $50 \%$ of the Aspergillus strains inhibited at $0.5 \mu \mathrm{g} / \mathrm{mL}$. The lower ITC MICs were observed against $A$. candidus and $A$. terreus (Table 2 ).

Amphotericin B had low MICs against the Aspergillus species tested, being the values below $2 \mu \mathrm{g} / \mathrm{mL}$ for 29 strains. However the AMB MIC for three strains were $2 \mu \mathrm{g} / \mathrm{mL}$ (A. flavus, A. niger, and A. terreus) e.g., breakpoint determined by the CLSI; and $4 \mu \mathrm{g} / \mathrm{mL}$ for one strain of $A$. flavus. The mean value for AMB MIC50 was $0.5 \mu \mathrm{g} / \mathrm{mL}$ against $A$. candidus, A. flavus, A. fumigatus, A. tamarii, and $A$. terreus. For $A$. niger this value was lower with MIC of $0.25 \mu \mathrm{g} / \mathrm{mL}$ for at least fifty per cent of strains. The strain UFMGLMCC05 (A. flavus) was classified as amphotericin B-resistant (AmB-R) and submitted to further analysis of resistance mechanism. Finally, TBF MIC values ranged between 0.003 and $1 \mu \mathrm{g} / \mathrm{mL}$ (Table 2).

\section{Amphotericin B-resistant versus susceptible $A$. flavus}

AmB-R A. flavus (UFMGLMCC05) was collected from the sediment in the disphotic zone of RM3 cave where whitish/yellowish mats of actinomycetes (including Streptomyces spp., unpublished data) covered the sediment. The AmB-S used for comparison was obtained from our mycological collection and was firstly isolated from a highly visited show cave with no visible growth of actinomycetes (Aspergillus flavus UFMGLMCC103, Maquiné Cave/Cordisburgo, $\mathrm{MG}$, Brazil). We have selected this AmB-S strain to eliminate possible local adaptive effects.

The AmB-R has higher levels of ergosterol than and AmB-S A. flavus in control media $(\mathrm{p}<0.05)$ and when exposed to AMB $(\mathrm{p}<0.05)$ (Fig. 2). Furthermore, the lipid peroxidation results (expresses as TBARS levels) showed that the AmB-R strain was less susceptible to oxidative stress caused by AMB and HP $(p<0.05)$ (Fig. 3). The investigation of enzymatic activities of PER and SOD in response to oxidative stress showed that PER activity was similar between the AmB-S and AmB-R when treated with AMB. When treated with HP, AmB-S had lower PER activity compared with a large increase in AmB-R strain (Fig. 3) ( $p<0.05)$. On the other hand, the SOD activity was higher $(p<0.05)$ in the AmB-R strain exposed to the drug and HP (Fig. 3).

\section{DISCUSSION}

Resistance to antibiotic compounds involve several mechanisms aimed at reducing drug content in the cell, decreasing interaction between the drug and its target, and metabolic modifications to counter balance the lethal effect of the drug (Vandeputte et al., 2012). It is evident that all mechanisms involved in drug-resistance result from an adaptive response and fitness enhancement (Anderson, 2005). This interaction is commonly triggered by contact with the drug due to soil/water contamination (clinical or agricultural use) or ecological interactions with organisms producing these antifungal agents in the
Table 2. Minimal Inhibitory Concentration (MIC) values $(\mu \mathrm{g} / \mathrm{mL})$ for amphotericin B (AMB), itraconazole (ITC), voriconazole (VCZ) and terbinafine (TBF) against thirty-two Aspergillus strains isolated from caves in Minas Gerais (Brazil).

\begin{tabular}{|c|c|c|c|c|}
\hline \multirow{2}{*}{$\begin{array}{c}\text { Taxon } \\
\text { (strain no.) }\end{array}$} & \multicolumn{4}{|c|}{$\mathrm{MIC}(\mu \mathrm{g} / \mathrm{mL})$} \\
\hline & AMB & ITC & VCZ & TBF \\
\hline \multicolumn{5}{|c|}{ Aspergillus candidus } \\
\hline UFMGLMCC03 & 1 & 0.5 & 8 & 0.0625 \\
\hline UFMGLMCC028 & 0.03 & 0.25 & 4 & 0.0625 \\
\hline UFMGLMCC 11 & 0.5 & 0.5 & 4 & 0.125 \\
\hline UFMGLMCC 15 & 0.5 & 0.5 & 4 & 0.003 \\
\hline $\operatorname{MIC} 50(\mu \mathrm{g} / \mathrm{mL})^{a}$ & 0.5 & 0.5 & 4 & 0.0625 \\
\hline \multicolumn{5}{|l|}{ Aspergillus flavus } \\
\hline UFMGLMCC04 & 0.5 & 4 & 4 & 0.125 \\
\hline UFMGLMCC05 & $4^{b}$ & 0.25 & 8 & 0.0625 \\
\hline UFMGLMCC06 & 0.5 & 4 & $>16^{b}$ & 0.0625 \\
\hline UFMGLMCC09 & 1 & 0.5 & 8 & 0.125 \\
\hline UFMGLMCC019 & 0.5 & 4 & 4 & 0.0312 \\
\hline UFMGLMCC021 & 0.5 & 0.5 & 8 & 0.0625 \\
\hline UFMGLMCC024 & 0.5 & 1 & $>16^{b}$ & 0.5 \\
\hline UFMGLMCC025 & 1 & 0.5 & 8 & $1^{b}$ \\
\hline UFMGLMCC026 & 1 & 0.5 & 8 & 0.0625 \\
\hline UFMGLMCC027 & 0.25 & 1 & 4 & 0.0625 \\
\hline UFMGLMCC030 & 2 & 4 & 4 & 0.001 \\
\hline UFMGLMCC033 & 1 & 8 & $16^{b}$ & 0.5 \\
\hline MIC $50(\mu \mathrm{g} / \mathrm{mL})$ & 0.5 & 1 & 8 & 0.0625 \\
\hline \multicolumn{5}{|c|}{ Aspergillus fumigatus } \\
\hline UFMGLMCC01 & 1 & 4 & 8 & 1 \\
\hline UFMGLMCC02 & 0.5 & 1 & 2 & 0.0625 \\
\hline UFMGLMCC07 & 1 & 4 & 4 & 0.125 \\
\hline UFMGLMCC013 & 0.5 & 0.5 & 4 & 0.0625 \\
\hline UFMGLMCC010 & 0.25 & 0.5 & 4 & 0.0625 \\
\hline UFMGLMCC022 & 0.5 & 4 & 8 & 0.003 \\
\hline MIC $50(\mu \mathrm{g} / \mathrm{mL})$ & 0.5 & 1 & 4 & 0.0625 \\
\hline \multicolumn{5}{|l|}{ Aspergillus niger } \\
\hline UFMGLMCC016 & 0.25 & 8 & 4 & 0.0625 \\
\hline UFMGLMCC017 & 0.25 & 8 & 4 & 0.001 \\
\hline UFMGLMCC018 & 0.25 & 8 & 8 & 0.0625 \\
\hline UFMGLMCC023 & 0.5 & 0.5 & 8 & 0.003 \\
\hline UFMGLMCC029 & 0.0125 & 0.25 & 8 & 0.0625 \\
\hline UFMGLMCC034 & 2 & 4 & 8 & 0.0625 \\
\hline MIC $50(\mu \mathrm{g} / \mathrm{mL})$ & 0.25 & 4 & 8 & 0.0625 \\
\hline \multicolumn{5}{|c|}{ Aspergillus tamarii } \\
\hline UFMGLMCC012 & 0.5 & 1 & 4 & 0.03 \\
\hline UFMGLMCC020 & 1 & 1 & 8 & 0.03 \\
\hline MIC $50(\mu \mathrm{g} / \mathrm{mL})$ & 0.5 & 1 & 4 & 0.03 \\
\hline \multicolumn{5}{|c|}{ Aspergillus terreus } \\
\hline UFMGLMCC031 & 2 & 0.5 & 4 & 0.25 \\
\hline UFMGLMCC032 & 1 & 0.25 & 4 & 0.125 \\
\hline MIC $50(\mu \mathrm{g} / \mathrm{mL})$ & 1 & 0.25 & 4 & 0.125 \\
\hline
\end{tabular}

${ }^{a}$ MIC50: MIC value which inhibits $50 \%$ of the strains

environment (Anderson, 2005; Vandeputte et al., 2012). Although recent studies have focused in investigating drug resistance and mechanisms involved among cave isolated bacteria (Bhullar et al., 2012), this is the first study that aimed at investigating drug resistance among cave isolated filamentous fungi. 


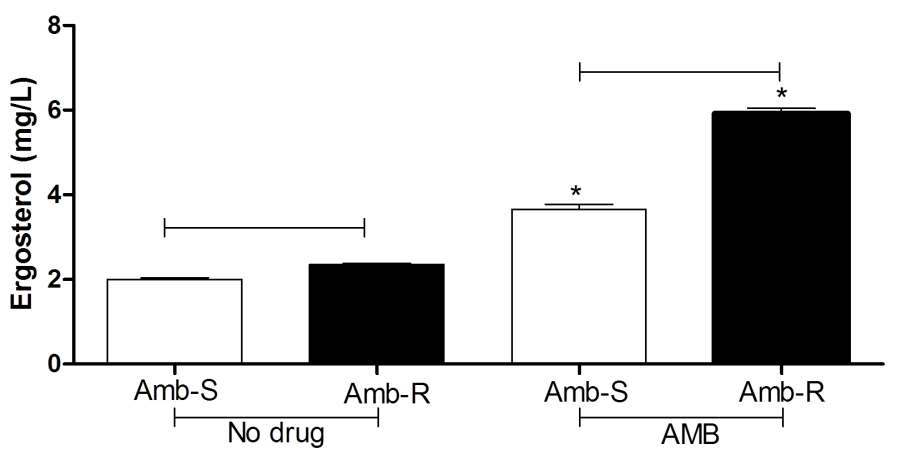

Fig. 2. Effect of amphotericin $B(A M B)$ in susceptible and resistant Aspergillus flavus strains. Results are expressed in $\mathrm{mg} / \mathrm{mL}$. Data are represented as the mean + SEM of two independent experiments in triplicate assays. Statistically significant differences between the treatment and the control (no drug) are indicated with connect lines and between susceptible and resistant strains are indicated with asterisks $(p<0.05)$. Amb-S = susceptible strain to amphotericin $B$; $A m b-R=$ resistant strain to amphotericin $B$.

A

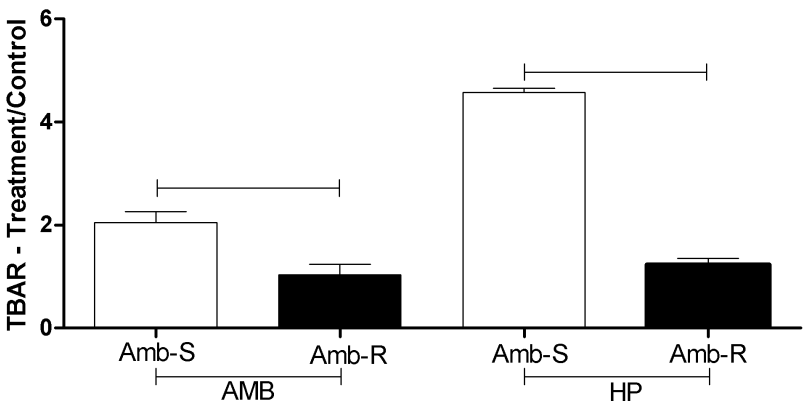

B
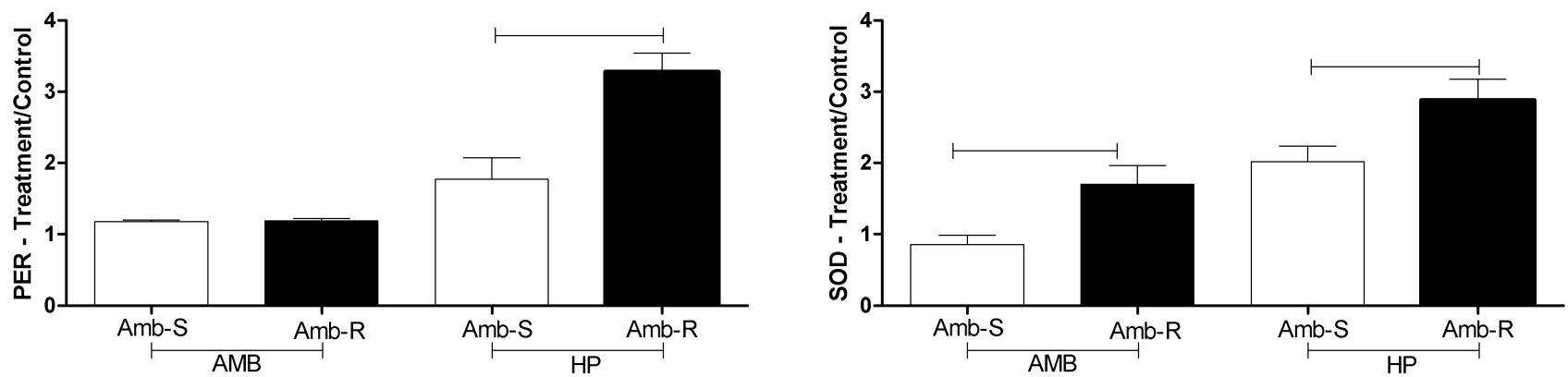

Fig. 3. Resistant cells are less susceptible to oxidative burst. (A) Lipid peroxidation (TBARs, thiobarbituric acid-reactive substances) (B) PER (peroxidase) (C) SOD (superoxide dismutase) activities after treatment with amphotericin B (AMB) and hydrogen peroxide (HP). Results are expressed as the ratio of the treatment to the control. Statistical differences are represented by the connect line $(p<0.05)$. Data represent the mean \pm S.E. of two independent experiments consisting of triplicate assays. Amb-S = susceptible strain to amphotericin $B ; A m b-R=r e s i s t a n t$ strain to amphotericin B.

Terbinafine had the lowest MICs among the cave isolated fungi and the lower MICs with no resistant strains. Although TBF is not usually used in treatment of invasive pulmonary aspergillosis (Kousha et al., 1999), its use combined with AMB and azoles has been investigated (Ryder \& Leitner, 2001; Mosquera et al., 2002; Cuenca-Estrella, 2004; Fernandez et al., 2015). Additive and synergistic relations have been reported between triazoles and TBF, as well as sinergism between AMB and TBF (Singh \& Paterson, 2005). Additionally the AmB-resistant A. flavus had low TBF MICs, which is a result that deserves further evaluation aimed at combined use of drugs.

Our results clearly showed that, among the azoles, ITC had lower MIC values against the strains tested when compared with VCZ. Döring and colleagues (2014) reported similar result with ITC in clinical strains obtained from paediatric patients. Indeed, it is important to highlight that our samples came from iron-rich sediment, which could be inducing resistance mechanisms against azoles as already observed in clinical and in vivo assays (Prasad et al., 2006; Craven et al., 2007; Zarember et al., 2009; Chowdhary et al., 2013; Hosogaya et al., 2013).

Hosogaya and colleagues (2013) showed a strong positive relation between iron concentrations and resistance to azoles in Candida glabrata. The authors showed that the protein Dap1 is indirectly involved in the ergosterol biosynthesis and their results suggested heme binding by Dap1 is crucial for Erg11 
activity and ergosterol biosynthesis, thereby being required for azole tolerance. Similar relation between iron depletion and susceptibility to azoles in yeasts (Prasad et al., 2006; Craven et al., 2007) and the filamentous fungi A. fumigatus (Zarember et al., 2009) has been reported. Our results open to a discussion on the role of iron concentrations in natural habitats and resistance to azoles that certainly deserves special attention in future investigations.

Despite its high toxicity, AMB is still used against IPA (Kousha et al., 1999). Amphotericin B MICs commonly range between 0.25 and $2 \mu \mathrm{g} / \mathrm{mL}$ (Kazemi et al., 2013) with resistance breakpoint at MIC $>2 \mu \mathrm{g} / \mathrm{mL}$ (CLSI, 2008). Although results with AMB were lower in our study (with MIC50 at $0.5 \mu \mathrm{g} / \mathrm{mL}$ ), a resistant strain of $A$. flavus was detected and other strains had MICs at breakpoint value (A. flavus and $A$. terreus). The high MICs observed in A. terreus to AMB, was not surprising, since resistance to AMB has already been reported for this species (Sutton et al., 1999; Singh \& Paterson, 2005). To our knowledge this is the first report of an AmB-resistant strain of $A$. flavus isolated directly from cave sediment. Resistance to AMB has already been documented for other Aspergillus species obtained from clinical samples (Blum et al., 2008; Van Der Linden et al., 2011; Hadrich et al., 2012).

Interestingly, the resistant strain was collected from the sediment of an aphotic site covered with numerous actinomycete colonies. As mentioned by Khoo et al. (1994), AMB was firstly obtained from filamentous bacteria (Streptomyces nodosus). It has been recently reported that other microorganisms inhabiting extreme environments also produce AMB as survival mechanism enhancing their ecological fitness in competing for substrate (Svahn et al., 2015). Additionally, Seo et al. (1999) induced resistance to AMB from a wild strain of $A$. flavus after several conidial transfers on AMB enriched media. This could be occurring naturally among wild strains in the environment. It is plausible to hypothesize that constant natural exposure to antifungal compounds produced by competitors (bacteria or fungi) induces natural selection of drug-resistant strains. Similar relation has been reported among cave isolated bacteria (Bhullar et al., 2012). The authors detected resistance to over fourteen antibiotics by bacteria isolated from a pristine cave in the United States and associated resistance with their pan genome and adaptive response to ecological interactions.

Concerning the investigation of resistance mechanisms, it has been widely considered that the main antifungal action of AMB derives from the binding between ergosterol and AMB altering membrane permeability and causing leackage of cytoplasmatic components (Ermishkin et al., 1976; Khoo et al., 1994; Johnson \& Einstein 2007; Laniado-Laborín \& Cabrales-Vargas, 2009). Thus, some authors have associated the main resistance mechanism to AMB with decrease of ergosterol content to diminish binding sites. Others pointed that ergosterol decrease is not the main resistance mechanism in Aspergillus spp. (Alcazar-Fuoli et al., 2006; Blum et al., 2008; Alcazar-
Fuoli \& Mellado, 2013) with resistance being more related with response to oxidative stress (Blum et al., 2013). Our results showed a substantial ergosterol increase in the AmB-R strain when exposed to the agent. It is important to highlight that ergosterol is involved in several relevant functions in fungi (e.g., hyphal growth, conidiation, protection) and its decrease has been classified as a secondary resistance mechanism (Laniado-Laborin \& Cabrales-Vargas, 2009; Mesa-Arango et al., 2014). Furthermore, the resistant strain showed lower susceptibility to free radicals, probably due to the overexpression of the antioxidant system. Our group previously showed that AMB led to ROS formation and lipid peroxidation in yeast cells (Cryptococcus gattil) and this phenomenon strongly increased the enzymatic activities of the antioxidant system (Ferreira et al., 2013).

The data obtained in the enzymatic assay (PER and SOD) showed that SOD played major role in the resistance of $A$. flavus isolated from RM3 cave. Fungal AMB-resistance has been related with enzymatic activity against oxidative stress for some fungi (Laniado-Laborín \& Cabrales-Vargas, 2009; Mesa-Arango et al., 2014). Blum et al. (2008) showed that AMB-resistance in A. terreus was highly related with catalase production. Okamoto et al. (2004) showed that oxidative damage induced by superoxide was the main activity of AMB against the yeast $C$. albicans. In the other hand, it seems that peroxidases did not play a crucial role in the resistance mechanism against AMB.

Caving is a common practice that has been increasing worldwide, causing various impacts on the subterranean biodiversity (Cigna, 1993; Souza-Silva, 2008; Lobo \& Moretti, 2009; Souza-Silva \& Ferreira, 2009; Kartalis et al., 2011; Taylor et al., 2013). The use of ground water and pieces of speleothems for curative purposes by local population should also be mentioned (Souza-Silva et al., 2011; Taylor et al., 2013) especially considering the impacts and risks posed by this activity. The transport of cave microorganisms and their contact with individuals of poor immunologic conditions enhance the chances of infection by drug-resistant strains. Despite being important components of cave biodiversity microbial communities have been poorly investigated in management plans and monitoring of subterranean ecosystems (Bhullar et al., 2012; Taylor et al., 2013; Vanderwolf et al., 2013). In the past decade, Brazilian governmental agencies have required more detailed microbiological inventories in caves to reduce chances of fungal outbreaks. Although the chances of developing pulmonary fungal infections by other species than Histoplasma capsulatum while caving are scarce, these opportunistic infections are emerging diseases and should be more thoroughly investigated, as well as their resistance mechanisms. The high resistance to AMB observed corroborates with the idea that antibiotic resistance might be a natural event, resulting from competition among soil organisms and their metabolites.

In conclusion, our findings broaden the knowledge concerning the action of AMB against $A$. flavus and the 
mechanisms of resistance involved. We also speculate that interactions with environmental conditions (e.g., iron concentration) and between organisms lead to an adaptive response towards natural selection of drug resistant microorganisms in caves.

\section{AKNOWLEDGEMENTS}

This study was supported by Fundação de Amparo a Pesquisa do Estado de Minas Gerais (FAPEMIG) and VALE S.A. RLF, DAS and MARS are research fellows of the National Council of Technological and Scientific Development $(\mathrm{CNPq})$. We are thankful to all staff involved and especially to Rafael Cardoso for the map.

Declaration of interest: The authors report no conflicts of interest. The authors alone are responsible for the content and writing of the paper.

\section{REFERENCES}

Alcazar-Fuoli L., Mellado E., Garcia-Effron G., Buitrago M.J., Lopez J.F., Grimalt J.O., Cuenca-Estrella J.M. \& Rodriguez-Tudela J.L., 2006 - Aspergillus fumigatus C-5 sterol desaturases Erg3A and Erg3B: role in sterol biosynthesis and antifungal drug susceptibility. Antimicrobial Agents and Chemotherapy, 50: 453-460. https://doi.org/10.1128/AAC.50.2.453-460.2006

Alcazar-Fuoli L. \& Mellado E., 2013 - Ergosterol biosynthesis in Aspergillus fumigatus: its relevance as an antifungal target and role in antifungal drug resistance. Frontiers in Microbiology, 3: 439. https://doi.org/10.3389/fmicb.2012.00439

Anderson J.B., 2005 - Evolution of antifungal-drug resistance: mechanisms and pathogen fitness. Nature Reviews Microbiology, 3: 547-556.

https://doi.org/10.1038/nrmicro1179

Bhullar K., Waglechner N., Pawlowski A., Koteva K., Banks E.D., Johnston M.D., Barton H.A. \& Wright, G.D., 2012 - Antibiotic resistance is prevalent in an isolated cave microbiome. PLoS One, 7: e34953. https://doi.org/10.1371/journal.pone.0034953

Blum G., Hörtnagl C., Jukic E., Erbeznik T., Pümpel T., Dietrich H., Nagl M., Speth C., Rambach G. \& Lass-Flörl C., 2013 - New insight into amphotericin $B$ resistance in Aspergillus terreus. Antimicrobial Agents and Chemotherapy, 57: 1583-1588.

https://doi.org/10.1128/AAC.01283-12

Blum G., Perkhofe S., Haas H., Schrettl M.,Würzner R., Dierich M.P. \& Lass-Flörl C., 2008 - Potential basis for amphotericin $B$ resistance in Aspergillus terreus. Antimicrobial Agents and Chemotherapy, 52: $1553-1555$.

https://doi.org/10.1128/AAC.01280-07

Chowdhary A., Kathuria S., Xu J. \& Meis J.F., 2013 -Emergence of azole-resistant Aspergillus fumigatus strains due to agricultural azole use creates an increasing threat to human health. PLoS Pathogens, 9: e1003633.

https://doi.org/10.1371/journal.ppat.1003633

Cigna A.A., 1993 - Environmental management of tourist caves. Environmental Geology, 21: 173-180. https://doi.org/10.1007/BF00775302

Clinical and Laboratory Standards Institute, 2008 - Reference method for broth dilution antifungal susceptibility testing of filamentous fungi. Approved Standard M38-A2.CLSI, Wayne, PA USA.
Craven R.J., Mallory J.C. \& Hand R.A., 2007 - Regulation of iron homeostasis mediated by the heme-binding protein Dap1 (damage resistance protein 1) via the P450 protein Erg11/ Cyp51. The Journal of Biological Chemistry, 282: 36543-36551. https://doi.org/10.1074/jbc.M706770200

Cuenca-Estrella M., 2004 - Combinations of antifungal agents in therapy: what value are they? Journal of Antimicrobial Chemotherapy, 54: 854-869. https://doi.org/10.1093/jac/dkh434

Culver D.C., White W.B., 2005 - Encyclopedia of Caves. Elsevier Press, Amsterdam, 654p.

Domsch K.H., Gams W. \& Anderson T.H., 2007 Compendium of soil fungi. Academic Press Inc, New York, $860 \mathrm{p}$.

Döring M., Blume O., Haufe S., Hartmann U., Kimmig A., Schwarze C.P, Lang P., Handgretinger R. \& Müller I., 2014 - Comparison of itraconazole, voriconazole, and posaconazole as oral antifungal prophylaxis in pediatric patients following allogeneic hematopoietic stem cell transplantation. European Journal of Clinical Microbiology \& Infectious Diseases, 33: 629-638. https://doi.org/10.1007/s10096-013-1998-2

Ermishkin L.N., Kasumov K.M. \& Potzeluyev V.M., 1976 - Single ionic channels induced in lipid bilayers by polyene antibiotics amphotericin $B$ and nystatine. Nature, 262: 698-699.

https://doi.org/10.1038/262698a0

Fernandez M.S., Rojas F.D., Cattana M.E., Sosa M.A., Iovannitti C.A., Lass-Flörl C. \& Giusiano, G.E., 2015 - In vitro activities of amphotericin $B$, terbinafine, and azole drugs against clinical and environmental isolates of Aspergillus terreus Sensu Stricto. Antimicrobial Agents and Chemotherapy, 59: 3619-3622.

https://doi.org/10.1128/AAC.00045-15

Ferreira G.F., Baltazar L.M., Santos J.R.A., Monteiro A.S., Fraga L.A.O, Resende-Stoianoff M.A. \& Santos, D.A., 2013 - The role of oxidative and nitrosative bursts caused by azoles and amphotericin $B$ against the fungal pathogen Cryptococcus gattii. Journal of Antimicrobial Chemotherapy, 68: 1801-1811. https://doi.org/10.1093/jac/dkt114

Ghannoum M.A. \& Rice L.B., 1999 - Antifungal agents: mode of action, mechanisms of resistance, and correlation of these mechanisms with bacterial resistance. Clinical Microbiology Reviews, 12: 501-517.

Griffin D.H., 1994 - Fungal Physiology. $2^{\text {nd }}$ ed., John Wiley \& Sons, New York, 472 p.

Hadrich I., Makni F., Neji S., Cheikhrouhou F., Bellaaj H., Elloumi M., Ayadi A. \& Ranque S., 2012 - Amphotericin $B$ in vitro resistance is associated with fatal Aspergillus flavus infection. Medical Mycology, 50: 829-834. https://doi.org/10.3109/13693786.2012.684154

Hosogaya N., Miyazaki T., Nagi M., Tanabe K., Minematsu A., Nagayoshi Y., Yamauchi S., Nakamura S., Imamura Y., Izumikawa K., Kakeya H., Yanagihara K., Miyazaki Y., Kugiyama K. \& Kohno S., 2013 - The heme-binding protein Dap1 links iron homeostasis to azole resistance via the P450 protein Erg11 in Candida glabrata. FEMS Yeast Research, 13: 411-421. https://doi.org/10.1111/1567-1364.12043

Iwen P.C., Rupp M.E., Langnas A.N., Reed E.C. \& Hinrichs S.H., 1998 - Invasive pulmonary aspergillosis due to Aspergillus terreus: 12-year experience and review of the literature. Clinical Infection Diseases, 26: 1092-1097. https://doi.org/10.1086/520297

Johnson R.H. \& Einstein H.E., 2007 - Amphotericin B and Coccidioidomycosis. Annals of the New York Academy of Sciences, 1111: 434-441.

https://doi.org/10.1196/annals.1406.019 
Kartalis N.D., Koulakiotis A. \& Niko T., 2011-Management accounting practises of tourism organizations: the case of the Greek show caves. Proceedings of the International Conference on Applied Economics, Perugia, Italy.

Kazemi A., Hossein N., Masood T. \& Shahram T., 2013 - In vitro activities of amphotericin $B$, itraconazole and voriconazole against isolates of Aspergillus spp. Bulletin of Environment, Pharmacology and Life Science, 2: 9-12.

Khoo S.H., Bond J. \& Denning D.W., 1994 - Administering amphotericin B: a practical approach. Journal of Antimicrobial Chemotherapy, 33: 203-213. https://doi.org/10.1093/jac/33.2.203

Klich M.A., 2002 - Identification of common Aspergillus species. Centraalbureau voor Schimmel Cultures. Utrecht, The Netherlands, 116 p.

Kousha M., Tadi R. \& Soubani A.O., 2011 - Pulmonary aspergillosis: a clinical review. European Respiratory Review, 20: 156-174. https://doi.org/10.1183/09059180.00001011

Laniado-Laborín R. \& Cabrales-Vargas M.N., 2009 - Amphotericin B: side effects and toxicity. Revista Iberoamericana de Micología, 26: 223-227.

https://doi.org/10.1016/j.riam.2009.06.003

Lobo H.A.S. \& Moretti E.C., 2009 - Tourism in caves and the conservation of the speleological heritage: The case of Serra da Bodoquena (Mato Grosso do Sul State, Brazil). Acta Carsologica, 38: 265-276. https://doi.org/10.3986/ac.v38i2-3.127

Loeffler J. \& Stevens D.A., 2003 - Antifungal drug resistance. Clinical Infectious Diseases, 36 (Supp1. 1): S31-S41. https://doi.org/10.1086/344658

Mesa-Arango A.C., Trevijano-Contador N., Román E., Sánchez-Fresneda, R., Casas, C., Herrero, E., Argüelles J.C., Pla J., Cuenca-Estrella M. \& Zaragoza O., 2014 The production of reactive oxygen species is a universal action mechanism of amphotericin $B$ against pathogenic yeasts and contributes to the fungicidal effect of this drug. Antimicrobial Agents and Chemotherapy, 58: 6627-6638. https://doi.org/10.1128/AAC.03570-14

Mokaddas E., Burhamah M.H.A., Ahmad S. \& Khan Z.U., 2010 - Invasive pulmonary aspergillosis due to Aspergillus terreus: value of DNA, galactomannan and (1-3)- $\beta$-D-glucan detection in serum samples as an adjunct to diagnosis. Journal of Medical Microbiology, 59: 1519-1523.

https://doi.org/10.1099/jmm.0.023630-0

Mosquera J., Sharp A., Moore C.B., Warn P.A. \& Denning D.W., 2002 - In vitro interaction of terbinafine with itraconazole, fluconazole, amphotericin $B$ and 5-flucytosine against Aspergillus spp. Journal of Antimicrobial Chemotherapy, 50: 189-194. https://doi.org/10.1093/jac/dkf111

Okamoto Y., Aoki S. \& Mataga I., 2004 - Enhancement to amphotericin $B$ activity against Candida albicans by superoxide radical. Mycopathologia, 158: 9-15.

https://doi.org/10.1023/B:MYCO.0000038430.20669.80

Perfect J.R., Cox G.M., Lee J.Y., Kauffman C.A., de Repentigny L., Chapman S.W., Morrison V.A., Pappas P., Hiemenz J.W. \& Stevens D.A., 2001 - The impact of culture isolation of Aspergillus species: a hospital-based survey of aspergillosis. Clinical Infectious Diseases, 33: 1824-1833. https://doi.org/10.1086/323900

Person K.A., Chudgar S.M., \& Norton L., 2010-Aspergillus niger: an unusual cause of invasive pulmonary aspergillosis. Journal of Medical Microbiology, 59: 834-883. https://doi.org/10.1099/jmm.0.018309-0

Poulson T.L. \& White W.B., 1969 - The cave environment. Science, 165: 971-980.

https://doi.org/10.1126/science.165.3897.971
Prasad T., Chandra A., Mukhopadhyay C.K. \& Prasad, R., 2006 - Unexpected link between iron and drug resistance of Candida spp.: iron depletion enhances membrane fluidity and drug diffusion, leading to drug-susceptible cells. Antimicrobial Agents and Chemotherapy, 50: 3597-3606. https://doi.org/10.1128/AAC.00653-06

Ryder N.S. \& Leitner I., 2001 - Synergistic interaction of terbinafine with triazoles or amphotericin $B$ against Aspergillus species. Medical Mycology, 39: 91-95.

https://doi.org/10.1080/mmy.39.1.91.95

Seo K., Akiyoshi H. \& Ohnishi Y., 1999 - Alteration of cell wall composition leads to amphotericin $B$ resistance in Aspergillus flavus. Microbiology and Immunology, 43: 1017-1025.

https://doi.org/10.1111/j.1348-0421.1999.tb01231.x

Singh N., 2001 - Trends in the epidemiology of opportunistic fungal infections: predisposing factors and the impact of antimicrobial use practices. Clinical Infectious Diseases, 33: 1692-1696.

https://doi.org/10.1086/323895

Singh N. \& Paterson D.L., 2005 - Aspergillus infections in transplant recipients. Clinical Microbiology Reviews, 18: 44-69. https://doi.org/10.1128/CMR.18.1.44-69.2005

Souza-Silva M., 2008 - Ecology and Conservation of Cave Invertebrate Communities in the Brazilian Atlantic Forest. PhD Thesis Post-Graduation Program in Ecology, Conservation and Management of the Wildlife, Federal University of Minas Gerais (UFMG).

Souza-Silva M. \& Ferreira R.L., 2009 - Ecological characterization of some caves in the National Park of Ubajara (Ceará) with considerations on tourism in these cavities. Revista de Biologia e Ciências da Terra, 1: 59-71.

Souza-Silva M., Martins R.P. \& Ferreira R.L., 2011 - Cave lithology determining the structure of the invertebrate communities in the Brazilian Atlantic Rain Forest. Biodiversity and Conservation, 8: 1713-1729. https://doi.org/10.1007/s10531-011-0057-5

Sutton D.A., Sanche S.S., Revankar S.G., Fothergill A.W. \& Rinaldi M.G., 1999 - In vitro amphotericin B resistance in clinical isolates of Aspergillus terreus, with a head-to-head comparison. Journal of Clinical Microbiology, 37: 2343-2345.

Svahn K.S., Chryssanthou E., Olsen B., Bohlin L. \& Göransson U., 2015 - Penicillium nalgiovense Laxa isolated from Antarctica is a new source of the antifungal metabolite amphotericin B. Fungal Biology and Biotechnology, 2: 1-6. https://doi.org/10.1186/s40694-014-0011-x

Taylor E.L.S., Ferreira R.L., Cardoso P.G. \& ResendeStoianoff M.A., 2014 - Cave entrance dependent spore dispersion of filamentous fungi isolated from various sediments of an iron ore cave in Brazil: a colloquy on human threats while caving. Ambient Science, 1: 16-28. https://doi.org/10.21276/ambi.2014.01.1.ra02

Taylor E.L.S., Resende-Stoianoff M.A. \& Ferreira R.L., 2013 - Mycological study for a management plan of a neotropical show cave (Brazil). International Journal of Speleology, 42: 267-277.

https://doi.org/10.5038/1827-806X.42.3.10

Van Der Linden J.W., Warris A. \& Verweij P.E., 2011 Aspergillus species intrinsically resistant to antifungal agents. Medical Mycology, 49 (Supp1. 1): S82-89. https://doi.org/10.3109/13693786.2010.499916

Vandeputte P., Ferrari S. \& Coste A.T., 2012 - Antifungal resistance and new strategies to control fungal infections. International Journal of Microbiology, 2012: 713687. https://doi.org/10.1155/2012/713687

Vanderwolf K.J., Malloch D., Mcalpine D.F. \& Forbes G.F., 2013 - A world review of fungi, yeasts, and slime mold in caves. International Journal of Speleology, 42: 77-96. https://doi.org/10.5038/1827-806X.42.1.9 
Walsh T.J., Anaissie E.J., Denning D.W., Herbrecht R., Kontoyiannis D.P., Marr K.A., Morrison V.A., Segal B.H., Steinbach W.J., Stevens D.A., van Burik J.A., Wingard J.R. \& Patterson T.F., 2008 - Treatment of aspergillosis: clinical practice guidelines of the Infectious Diseases Society of America. Clinical Infectious Diseases, 46: 327-360. https://doi.org/10.1086/525258
Zarember K.A., Cruz A.R., Huang C.Y. \& Gallin J.I., 2009 - Antifungal activities of natural and synthetic iron chelators alone and in combination with azole and polyene antibiotics against Aspergillus fumigatus. Antimicrobial Agents and Chemotherapy, 53: 26542656.

https://doi.org/10.1128/AAC.01547-08 